\title{
Free Trade and Deregulated Domestic Markets: Attitudes of Commercial Farmers in KwaZulu- Natal
}

\author{
R C Stockil and G F Ortmann \\ Department of Agricultural Economics, University of Natal, Pietermaritzburg
}

\begin{abstract}
This study analyses farmers' attitudes towards free trade and deregulated domestic product and input markets using a survey conducted in 1996 among 112 commercial farmers in KwaZulu-Natal. Most respondents were in favour of liberalised trade and deregulated domestic markets, but expected a decline in product prices, farm profits and land values. Logit analyses of farmers personal and business characteristics that influence their attitudes towards free trade and deregulated domestic markets were conducted. Results indicate that improved information on risk management practices and import tariff levels may help commercial farmers to adapt to a changing economic environment and reduce resistance to free trade.
\end{abstract}

\section{INTRODUCTION}

The Uruguay Round of the General Agreement on Tariffs and Trade (GATT), which was formally concluded on 15 December 1993 among 117 participating countries, aims to liberalise international trade (Giardini, 1995). In 1990, South Africa had 21 agricultural marketing boards which had a profound influence over domestic product prices, imports and exports, and the manner in which agricultural products were marketed. With the exception of most vegetables and subtropical fruit, marketing of primary food and fibre agricultural products was managed in some or other form by producer-dominated marketing boards (Swart, 1996). 
South Africa is a signatory to the GATT, resulting in increased market access here and abroad, reduced domestic support and export subsidies, and a revision of sanitary and phytosanitary measures (Department of Agriculture. 1994). Consequently, the elimination of producer controls over imports, tarification of agriculnural imports, the removal of most single channel marketing schemes and a general reduction in the authority of marketing boards has been experienced. The remaining 15 marketing boards perform mainly non-trade distorting functions such as generic advertising and market information (Swart, 1996). Amendments to international trade policy, together with improved dispute settlement procedures and monitoring provided by the Committee on Agriculture in the World Trade Organisation (WTO), will create conditions favourable for more stable international agricultural trade flows. Agricultural production will therefore be determined more by comparative advantage rather than the size of national budgets. Trade liberalisation will also increase import competition forcing industries to improve productivity through the adoption of innovations (MacLaren, 1995). International prices of agricultural products are expected to increase in the medium term following reduced supply from developed countries that pay high export subsidies (Department of Agriculture, 1994). However, technological improvements may reduce prices in the long term (Goldin and Knudsen, 1990). A greater degree of price uncertainty faced by commercial farmers is also expected in the event of reduced government protection (Lyne and Ortmann, 1992).

The objectives of this paper are (1) to ascertain farmers' responses to GATT and deregulated domestic markets, and (2) to determine the factors influencing attitudes of commercial farmers in KwaZulu-Natal towards free trade and deregulated domestic markets by using logit models. Education and improved information flows can help farmers to survive in a changing policy and trade environment, and it is for this reason that factors affecting farmers' perceptions towards free trade are important. Following Kastens and Goodwin (1994), this paper analyses farmers' attitudes regarding a non-specific policy environment in which no particular agricultural programme is evaluated, which differs from other studies. The paper concludes with a discussion of the management and policy implications of the results obtained.

\section{PAST RESEARCH ON ATTITUDES TOWARDS LIBERALISED TRADE}

Farmers are assumed to be rational, profit maximising decision makers and will therefore support agricultural policies in which they perceive the greatest benefit (Orazem et al, 1989; Barkley and Finchbaugh, 1990). Research in the USA has 
shown that farm operators with higher levels of education and experience display a resistance towards policy liberalisation because they are better able to comprehend the complex regulations and resulting benefits of agricultural programmes and are less suspicious of these programmes (Kastens and Goodwin, 1994; Barkley and Flinchbaugh, 1990).

Farmers who, assessed on a subjective basis, are less risk averse are less opposed to the riskier marketing conditions resulting from trade liberalisation. Farmers operating a greater proportion of rented land were more likely to support a free trade policy environment (Kastens and Goodwin, 1994). Specialised farms, probably because of their riskier nature, are less likely to support liberalisation than diverse operations and farm types enjoying relatively high levels of government support, which are again expected to oppose policy liberalisation (Kastens and Goodwin, 1994).

Larger farms in the USA show a greater degree of support for policy liberalisation. This may be as a result of limitations placed on individual farmers' benefits, or may indicate that larger farmers perceive greater benefits from economies of size in a free trade and free market environment. If farmers' perceptions are correct, policy liberalisation may lead to increased farm size (Kastens and Goodwin, 1994). Edelman and Lasley (1988) indicate that amongst USA farmers, acres owned and com acres were significantly positively related to pursuing an open market and there was a positive relationship between decoupling (which provides direct support to farmers but does not distort production, consumption and trade) and farm size. Conversely, research by Orazem et al (1989) indicates that the largest farms tend to oppose decoupling because it would result in lower crop prices and returns per hectare.

As farmers' wealth (net worth) increases, their preference for a liberalised policy environment rises (Kastens and Goodwin, 1994). Farmers under financial stress are less likely to support market-orientated domestic policies or the elimination of domestic policies because of increased price risk (Edelman and Lasley, 1988). The greater the number of days worked off the farm, the lower is the support for the continuation of present government programmes as producers with significant off-farm income are less dependent on government programmes and are thus more likely to support market liberalisation (Edelman and Lasley, 1988; Barkley and Flinchbaugh, 1990). 


\section{DATA SOURCE AND CHARACTERISTICS OF RESPONDENTS}

This study was conducted in 1996. The target population of 4436 commercial farmers in KwaZulu-Natal was stratified following Lyne and Ortmann (1996) and randomly sampled. The first stratum, constituting bioclimatic groups 1 and 2 (Phillips, 1973), is termed the Coastal Belt. Bioclimatic groups 3, 4, 5, 6 and 8 represent the KwaZulu-Natal Midlands, whilst bioclimatic groups 7, 9, 10 and 11 comprise the Lowveld region. A questionnaire was mailed to 578 farmers yielding 149 responses $(25,8$ percent) of which 112 (19,4 percent) were usable. The nonusable questionnaires were due to missing values, the sale of farming operations, or the retirement of some farmers. Twenty-six usable questionnaires were received from each of the Coastal and Lowveld regions, whilst 60 usable questionnaires were returned by Midlands farmers.

Respondents were on average 49,5 years of age, had 24,3 years of farming experience and 14,1 years of formal education. Sixty percent of respondents were individual owners of their farm business, 12 percent of the operations were close corporations, 10 percent companies, nine percent trusts and nine percent of respondents operated partnerships. Thirty-nine percent of respondents were employed to manage the farming operations. Computers were owned and used in the farm business by 64 percent of respondents, which is much higher than the 48 percent reported by Woodburn et al.(1994).

The average area operated in the Coastal Belt was 511 hectares (median 313 hectares), 1121 hectares in the Lowveld region (median 253 hectares, due to a predominance of irrigated sugar-cane farms and a few large extensive beef enterprises), and 866 hectares in the Midlands (median 604 hectares). More than 70 percent of gross farm income was derived from sugar-cane production by 75 percent of farmers in the Coastal Belt. Sixty-two percent and 15 percent of farmers in the Lowveld region derived more than 70 percent of gross farm income from sugar-cane and beef production respectively. The Midlands region is characterised by mixed farming activities. Among the farmers who received 70 percent or more of their gross income from a single enterprise, 27 percent were beef farmers, 12 percent dairy farmers, 10 percent sugar-cane farmers, eight percent timber farmers and six percent pig farmers.

About 86 percent of respondents were full-time farmers. Median household income from off-farm employment (including spouse's income) was R47 375 for the 35 percent of respondents who indicated off-farm employment (by themselves or their spouse). Estimated market values of assets, debt/asset levels and farm turnover (gross income) in a normal year for the three regions are presented in 
Table 1. The Coastal Belt had the highest mean turnover and debt/asset ratio, followed by the Lowveld and Midlands regions respectively. The debt/asset ratio should preferably be less than 0,5 (Barry et al., 1995). At a nominal interest rate of 15 percent, farmers will experience cash flow problems if borrowed capital exceeds one-third of the value of farmland, as the return to farmland in approximately five percent (Nieuwoudt and Vink, 1995). The ratios presented in Table 1 indicate that sample farmers were solvent. Ninety-two percent of respondents had ratios of less than 0,30 .

Table 1: Farm asset values, debt/asset ratios and turnover of sample farms in three regions of KwaZulu-Natal, February 1996.

\begin{tabular}{|c|c|c|c|c|c|c|c|c|c|}
\hline & \multicolumn{3}{|c|}{ Asset value (Rm) } & \multicolumn{3}{|c|}{ Debu/asset ratio } & \multicolumn{3}{|c|}{ Tumover (Rm) } \\
\hline & $\mathbf{n}$ & Mean & Median & n & Mean & Median & $\mathbf{n}$ & Mean & Median \\
\hline $\begin{array}{l}\text { Coastal } \\
(n=26)\end{array}$ & 25 & 5,612 & 3,691 & 18 & 0,149 & 0,141 & 22 & 2.086 & 1.471 \\
\hline $\begin{array}{l}\text { Lowveld } \\
(n=26)\end{array}$ & 25 & 5,676 & 3,800 & 25 & 0,131 & 0,116 & 26 & 1.594 & 1.076 \\
\hline $\begin{array}{l}\text { Midlands } \\
(n=60)\end{array}$ & 50 & 2,709 & 1.670 & 48 & 0,083 & 0,012 & 54 & 1.147 & 0,620 \\
\hline
\end{tabular}

Land is cash-rented by 21 percent of respondents, with the area rented ranging from 10 to 900 hectares (mean of 264 hectares). Two respondents were involved in share-lease agreements ( 50 and 100 hectares), while a single respondent rented out land (150 hectares).

\section{RESPONSES TO GATT AND DEREGULATED DOMESTIC MARKETS}

Given coverage of GATT (today the WTO) in the popular press and farming magazines, it was anticipated that most respondents would be aware of changes to international agricultural policy. GATT focuses primarily on reducing tariff barriers to trade in industrial and agricultural products (Schuh, 1995). Signatories to GATT are required to reduce internal support (Giardini, 1995), all non-tariff barriers are to be converted to tariffs, individual tariff lines reduced and import opportunities must be allowed for to facilitate opening-up of markets (Josling, 1993). The volume of subsidised exports is to be reduced and sanitary and phytosanitary (SPS) measures revised and tightened (Giardini, 1995). 
Only one respondent indicated that he was not aware of GATT. Seventy percent of respondents gained information on GATT by reading newspapers, whilst 45 and 31 percent obtained information from Effective Farming and Farmer's Weekly respectively. Twenty-eight percent indicated attendance at farmers' days whilst Financial Mail, Landbou Weekblad and industry publications (eg Sugar Joumal) were used by 23 percent of respondents to gain information on GATT. Private consultants were employed by 10 percent of respondents, nine percent read Finance Week, six percent read Finansies en Tegniek, and only five percent made use of extension officers. Sixty percent of respondents intended seeking additional information on GATT.

Fifty-two percent of respondents expected a decrease in their crop prices in the event of the successful implementation of the GATT requirements, whilst 25 percent expected their crop prices to increase. A decrease in livestock prices was expected by 61 percent of respondents and 12 percent thought that livestock prices would increase. Approximately equal proportions of respondents expected input prices to decrease (43 percent) and increase ( 39 percent). However, a greater proportion of crop and livestock producers (i.e. those who realised more than 55 percent of their gross income from either crop or livestock production respectively) thought a decrease in input prices likely. As is shown in Table 2, about one-half of respondents foresaw a decline in farm profits and 38 percent a fall in land values if the GATT requirements are successfully implemented.

Following the reduction of import tariffs on meats in 1995, beef respondents experienced a 24 percent decrease in beef prices. Poultry farmers indicated a 29 percent reduction in broiler prices, mutton farmers a 16 percent decrease in mutton prices, and pork farmers a 17 percent decrease in pigmeat prices. Seventy-seven percent of respondents did not know the level of import tariffs on the products they produced, whilst 90 percent did not know the levels of import tariff on the inputs they used. 
Table 2: Percentage of respondents expecting changes to product and input prices, farm profits and land values following the GATT provisions, 1996.

\begin{tabular}{|c|c|c|c|c|}
\hline & $\begin{array}{l}\text { Decrease } \\
\text { (percent) }\end{array}$ & $\begin{array}{l}\text { Increase } \\
\text { (percent) }\end{array}$ & $\begin{array}{l}\text { No change } \\
\text { (percent) }\end{array}$ & $\begin{array}{l}\text { Uncertain } \\
\text { (percent) }\end{array}$ \\
\hline Crop prices $(n=103$ ) & 52 & 25 & 14 & 9 \\
\hline Livestock prices $(n=87)$ & 61 & 12 & 10 & 17 \\
\hline Input prices $(n=108)$ & 43 & 39 & 11 & 7 \\
\hline Crop farmers ${ }^{*}(n=54)$ & 45 & 35 & 11 & 9 \\
\hline $\begin{array}{l}\text { Livestock farmers } \\
(\mathrm{n}=37)\end{array}$ & 49 & 38 & 8 & 5 \\
\hline Farm profits $(n=109)$ & 49 & 19 & 16 & 16 \\
\hline Land values $(n=110)$ & 38 & 14 & 22 & 26 \\
\hline
\end{tabular}

"Farmers who received more than 55 percent of their gross income from either crops or livestock.

A five-category scale, ranging from 'strongly disagree' with the statement given to 'strongly agree' (Table 3), was used to elicit farmers' attitudes towards free trade. For the various questions posed, between 59 and 92 percent of respondents were in favour of free trade. Ninety-two percent of respondents were in favour of the deregulation of domestic product and input markets, indicating that they perceived the recent deregulation of product marketing boards to be of benefit to their farm businesses. This conclusion may not apply generally as approximately 74 percent of the original 578 farmers in the sample did not return the questionnaire, while those who did may have definite views on liberalised trade.

Thirty-nine percent of all respondents, including 31 percent of livestock producers and 40 percent of crop farmers, would respond to further reduction in import tariffs by adjusting their farming operations. In the event of complete deregulation of domestic product and input markets, 48 percent of respondents, including 49 percent of livestock producers and 46 percent of crop farmers, would alter their farming operations. A greater proportion of crop farmers are concerned with further reduction in import tariffs, while nearly one-half of livestock producers are concerned with the complete deregulation of domestic markets. The recent high maize price, following on the deregulation of the maize industry, may be of concern to livestock producers. A large proportion of sugar-cane producers 
in the sample may have been concerned about changes in the domestic sugar price resulting from reduced import tariffs.

Of the respondents who considered altering their cost structure in response to successful implementation of the GATT provisions, 29 percent would reduce labour employment, increase use of machinery, and maintain fertilizer use at current levels. Of the 45 percent of respondents who would change the size and mix of enterprises currently operated, 46 percent would increase the size of current enterprises. Both enterprise diversification (adding a new enterprise) and changing the relative sizes of current enterprises were suggested by 23 percent of respondents. Reducing enterprise size (four percent of respondents) and changing farm enterprises totally (four percent) were also considered.

Table 3: Response of sample farmers to statements regarding a free trade environment, 1996.

\begin{tabular}{|c|c|c|c|c|c|}
\hline \multirow[b]{2}{*}{ Statement } & \multicolumn{5}{|c|}{ Percentage of respondents in each category } \\
\hline & $\begin{array}{l}\text { Strongly } \\
\text { disagree }\end{array}$ & Disagree & $\begin{array}{l}\text { Un- } \\
\text { certain }\end{array}$ & Agree & $\begin{array}{l}\text { Strongly } \\
\text { agree }\end{array}$ \\
\hline $\begin{array}{l}\text { Free, unrestrained international } \\
\text { trade (without the interference of } \\
\text { governments both here and } \\
\text { abroad) is beneficial for South } \\
\text { African farmers }(n=109) \text {. }\end{array}$ & 5 & 16 & 20 & 50 & 9 \\
\hline $\begin{array}{l}\text { A free. open market system of } \\
\text { trade (ie. one without govemment } \\
\text { intervention) should be pursued by } \\
\text { all food exporting and importing } \\
\text { countries by reducing all trade } \\
\text { barriers }(n=110 \text { ). }\end{array}$ & 2 & 18 & 13 & 51 & 16 \\
\hline $\begin{array}{l}\text { Farmers in all countries exporing } \\
\text { agricultural commodities should } \\
\text { not receive any government } \\
\text { support }(n=111) \text {. }\end{array}$ & 4 & 11 & 7 & 52 & 26 \\
\hline $\begin{array}{l}\text { South African farmers should } \\
\text { compete in a deregulated (free) } \\
\text { domestic product market, if input } \\
\text { markets are also deregulated } \\
(n=110) .\end{array}$ & 0 & 3 & 5 & 71 & 21 \\
\hline
\end{tabular}


Of the 64 percent of respondents who would respond to reduced import tariffs and/or complete domestic market deregulation, 46 percent would seek additional marketing information to aid management decisions and 44 percent would add value to their products. Forty percent of respondents considered purchasing additional technology to improve productivity, 35 percent considered exporting products, 32 percent employing machinery contractors and 24 percent would employ labour contractors. Employing the services of a private consultant or restructuring debt commitments were considered by 22 percent of respondents, 19 percent indicated engaging in forward contracts, 18 percent borrowing less capital or reducing family drawings, and 10 percent would trade on the futures market (SAFEX). The relatively small proportion of respondents considering trading on the futures market could possibly be due to the limited range of contracts currently available (eg there are no sugar contracts at present). Selling land was considered by 12 percent of respondents, 10 percent intended seeking off-farm employment, nine percent would introduce capital invested off the farm into the farm business, and six percent would sell assets or borrow more capital.

Sample farmers were also asked to rate their level of management skill relative to other farmers in their district on a five-point Likert-type scale (where 1 $=$ low and $5=$ high). The average rating for their managerial ability in farm production and overall farm management was 3,72 , in farm finance 3,61 , and 3,11 for product marketing. In the past, 21 marketing boards marketed about 90 percent of the total value of agricultural production (Lyne and Ortmann, 1992), thereby reducing the need for farmers to market their products. For farmers to survive in a deregulated policy and trade environment with increased price risk, product marketing skills will need to be improved and/or marketing experts employed.

\section{FARMERS' ATTITUDES TOWARDS FREE TRADE AND DEREGULATED DOMESTIC MARKETS}

The personal, financial and farm size characteristics of farm operators may be important factors influencing their attitudes towards free trade (Kastens and Goodwin, 1994). Consequently, the objective of this section is to determine the personal and business characteristics of respondents that influence their perceptions regarding free trade. A logit model is developed for this purpose. The dependent variable $\left(\mathrm{Y}_{i}\right)$ is dichotomous, scoring one if the respondent agreed with free trade (or deregulated domestic markets), and zero otherwise.

Equation (1) can be used to estimate the log odds of the probability of an event occurring, in this case the probability that a respondent will favour a free- 
trade environment. Respondents who 'strongly disagreed' or 'disagreed' with the statement regarding free trade (first question in Table 3) were allocated a zero, while respondents who 'agreed' and 'strongly agreed' were coded a one. 'Uncertain' responses were excluded from the analysis.

$$
\operatorname{In}\left[p_{i} /\left(1-p_{i}\right)\right]=a+\sum_{k=1}^{n} \beta_{k} X_{k i}
$$

where $p_{i}$ is the probability of the ith respondent favouring a free-trade environment and $X_{k}$ the kth explanatory variable. The dependent variable $\ln \left[\mathrm{p}_{\mathrm{i}} /\left(1-\mathrm{p}_{\mathrm{i}}\right)\right]$ is the natural $\log$ of the odds ratio in favour of the ith respondent being in favour of free trade (Gujarati, 1995).

\section{Independent variables considered in the model}

Based on previous studies discussed above, personal characteristics considered include years of farming experience, level of education, and willingness to take risks. Proportion of land rented, farm type, turnover (farn size), operator's wealth (net worth), off-farm employment, distance to nearest town, the debt/asset ratio, and a measure of financial stress (incorporating both solvency and liquidity measures) were the business characteristics considered. Exploratory analysis was also pursued to determine other factors affecting farmers' attitudes towards free trade. Variables which were hypothesised to have an impact on free-trade attitudes are defined in Table 4.

Hypothesised relationships between free-trade attitudes and EXP, EDU, RENT, SIZE, NWORTH and RISK are consistent with those of past studies. Increased price risk is expected with free trade, and thus farmers who have to contend with the additional financial risk associated with borrowed capital (D/A, FSTRESS, FFOPT and REPAY) are likely to oppose free trade.

Beef (BEEF) and sugar-cane (SUGAR) farmers are likely to be faced with reduced product prices under free-trade conditions (lower tariffs), and most beef farmers are unlikely to benefit substantially from reduced input costs under free trade owing to the extensive namure of production. These farmers are also expected to oppose free trade. Milk is highly perishable and thus not easily exportable, and opportunities exist to add value to it. However, increased competition from dairy products originating mainly in the EU and New Zealand may lead to lower 
product prices. Dairy farmers (DAIRY) are, therefore, hypothesised to oppose free trade too.

COMPUT is expected to have a positive effect on farmers' free-trade attitudes as it is a measure of farmer progressiveness. Rapid information flows are vital in a free market, and farmers using computers can develop a competitive edge over other farmers due to more timeous information. DIST is expected to have a negative relationship because proximity to markets is an important advantage to farmers if they are to market their own products.

Table 4: Definition of variables expected to influence farmers' attitudes towards free trade.

\begin{tabular}{|c|c|c|}
\hline Variable & Definition & $\begin{array}{l}\text { Expected } \\
\text { relation- } \\
\text { ship }\end{array}$ \\
\hline EXP & Years of farming experience. & - \\
\hline EDU & Years of formal education. & - \\
\hline RENT & Percentage of the total area operated that is rented. & + \\
\hline SIZE & $\begin{array}{l}\text { Annual gross income from farming operations } \\
\text { (Rand). }\end{array}$ & + \\
\hline NWORTH & Net worth of farm business (Rand). & + \\
\hline RISK & $\begin{array}{l}\text { Farmers willingness to take risks relative to other } \\
\text { farmers in the district (measured on a Likert-type } \\
\text { scale ranging from } 1=\text { much less willing to } 5= \\
\text { much more willing). }\end{array}$ & + \\
\hline $\mathrm{D} / \mathrm{A}$ & Debt to asset ratio. & - \\
\hline FSTRESS & $\begin{array}{l}\text { Measure of financial stress (liquidity and solvency) } \\
\text { scoring } 0 \text { if low up to } 4 \text { if high (Orazem et al, } \\
1989 \text { ). }\end{array}$ & - \\
\hline FFOPT & $\begin{array}{l}\text { Fixed financial obligations as a proportion of } \\
\text { turnover. }\end{array}$ & - \\
\hline REPAY & $\begin{array}{l}\text { Value of medium and long term debt repayments } \\
\text { (R100 000). }\end{array}$ & - \\
\hline BEEF & $\begin{array}{l}\text { Dummy variable }=1 \text { if more than } 55 \text { percent of } \\
\text { gross income is derived from beef production, } 0 \\
\text { otherwise. }\end{array}$ & - \\
\hline SUGAR & $\begin{array}{l}\text { Dummy variable }=1 \text { if more than } 55 \text { percent of } \\
\text { gross income is derived from sugar-cane } \\
\text { production, } 0 \text { otherwise. }\end{array}$ & - \\
\hline
\end{tabular}


Table 4 (continued)

\begin{tabular}{|c|c|c|}
\hline DAIRY & $\begin{array}{l}\text { Dummy variable }=1 \text { if more than } 55 \text { percent of } \\
\text { gross income is derived from dairy production, } 0 \\
\text { otherwise. }\end{array}$ & - \\
\hline COMPUT & $\begin{array}{l}\text { Dummy variable }=1 \text { if a computer is used in the } \\
\text { farm business, } 0 \text { otherwise. }\end{array}$ & + \\
\hline DIST & Distance of farm from nearest town $(\mathrm{km})$. & - \\
\hline ENVIRO & $\begin{array}{l}\text { Rating of changes in environmental regulations as } \\
\text { a source of risk }(1=\text { low and } 5=\text { high })^{*} \text {. }\end{array}$ & - \\
\hline RISKFAC & $\begin{array}{l}\text { Factor consisting of variability in crop prices, } \\
\text { changes in the Rand exchange rate, changes in } \\
\text { costs of inputs and further reduction of tariffs on } \\
\text { imported farm products as sources of risk, as per } \\
\text { section } 5(b)(1=\text { low and } 5=\text { high for all sources } \\
\text { of risk). }\end{array}$ & - \\
\hline LPRICE & $\begin{array}{l}\text { Rating of variability in livestock prices as a source } \\
\text { of risk }(1=\text { low and } 5=\text { high }) \text {. }\end{array}$ & - \\
\hline LANDP & $\begin{array}{l}\text { Dummy variable }=I \text { if farmer expects land prices } \\
\text { to increase if GATT provisions are successfully } \\
\text { implemented, } 0 \text { otherwise. }\end{array}$ & + \\
\hline LANDRED & $\begin{array}{l}\text { Rating of further land redistribution and } / \text { or } \\
\text { restitution by government as a source of risk }(1= \\
\text { low and } 5=\text { high). }\end{array}$ & + \\
\hline MFINAN & $\begin{array}{l}\text { Self-rating of management skill in farm finance (1 } \\
=\text { low and } 5=\text { high). }\end{array}$ & + \\
\hline PORF & $\begin{array}{l}\text { Dummy variable }=1 \text { if respondent is involved } \\
\text { full-time in the farming operation, } 0 \text { otherwise. } \\
\text { PORF is an inverse measure of off-farm income. }\end{array}$ & - \\
\hline TLEVEL & $\begin{array}{l}\text { Dummy variable }=1 \text { if respondent indicated some } \\
\text { knowledge of tariff levels on products sold or } \\
\text { inputs used, } 0 \text { otherwise. }\end{array}$ & - \\
\hline
\end{tabular}

All ratings. where $1=$ low and $5=$ high. ane based on a Liken-type scale

Farmers who attach greater importance to various risk sources are expected to have a negative attiude towards free trade (which gives rise to greater price risk). Hence, the variables ENVIRO, RISKFAC and LPRICE are expected to have a negative relationship with the dependent variable. Note that RISKFAC was developed for the following reason: Variability in crop prices, changes in the Rand exchange rate, changes in the cost of inputs and further reduction of import tariffs on agricultural products are sources of risk expected to influence respondents' 
attitudes towards free trade. Multicollinearity was anticipated among these variables owing to significant (one percent) zero-order correlation coefficients. A factor (RISKFAC), explaining 51 percent of the variation in these variables, was therefore created.

Farmers expecting profits, and thus land prices (LANDP), to fall (rise) under free trade conditions are expected to have a negative (positive) attitude towards free trade. However, farmers who perceive further land redistribution as a source of risk (LANDRED) may see an opportunity in free trade to secure their land base if they can become relatively more competitive. If this is the case, a positive relationship between LANDRED and attitudes towards free trade is expected.

MFINAN is hypothesised to have a positive effect on free-trade attitudes. Farmers who rate their financial skills highly most probably manage financial risk more effectively and are thus in a better position to manage increased price risk under free trade.

Previous studies have reported a positive relationship between off-farm income earned by farmers and their attitude towards free trade; these farmers are less reliant on income from government programmes (eg Orazem et al, 1989; Barkley and Flinchbaugh, 1990). Hence, a negative relationship is expected between PORF and attitudes towards free trade.

Knowledge of tariff levels is also expected to influence free-trade attitudes. Reduction of tariffs on imported products is expected to reduce local prices and hence farmers' profits. However, lower import tariffs on farm inputs are expected to have a positive effect on farmers' finances owing to lower input costs. Hence, if farmers have more knowledge of (or are more concerned with) tariffs on imported farm products than of input tariffs, a negative relationship between TLEVEL and attitudes towards free trade is expected.

The general logit model can now be defined as:

$$
\begin{aligned}
& \ln [p i /(1-p i)]=\quad \beta n+\beta_{1} \mathrm{EXP}_{i}+\beta_{2} \mathrm{EDU}_{i}+\beta_{3} \mathrm{RENT}_{i}+\beta_{4} \mathrm{SIZE}_{i}+ \\
& \beta \text { NWORTH }_{i}+\beta_{6} \text { RISK }_{i}+\beta_{\text {D }} / A_{i}+\beta_{3} \text { FSTRESS }_{i}+ \\
& \beta_{3 F_{F O P T i}}+\beta_{10 R E P A Y_{i}}+\beta_{11} \text { BEEFi }_{i}+\beta_{12} \text { SUGAR }_{i}+ \\
& \beta_{13} \text { DAIRY }_{i}+\beta_{14} \text { COMPUT }+\beta_{15 D I S T}+ \\
& \beta_{16} \text { ENVIRO }_{i}+\beta_{17 R I S K F A C ~}+\beta_{18 L P R I C E}+ \\
& \beta_{19} \text { LANDP }_{i}+\beta_{2} \text { TLEVELi }
\end{aligned}
$$




\section{Results of the analysis}

Independent variables included in other studies proved to be poor determinants of farmers' attitudes towards free rrade in this study. This may be due to a relatively small sample and lack of variation in the data. Only variables with coefficients significant at the ten percent (or higher) level of probability were retained in the logit model. Results of the analysis are presented in Table 5.

The model Chi-square statistic is highly significant. The goodness of fit statistic shows no significant lack of fit in the overall model. The estimated model correctly classifies 92,59 percent (50 of 54) of those in favour of free trade and $75,00$ percent ( 12 of 16$)$ of those opposed to free trade, yielding an overall correct classification rate of 88,57 percent ( 62 of 70 ).

Large standardised parameter estimates indicate that a unit change in the independent variable will have a large effect on the log of the odds ratio of a respondent agreeing with free rrade relative to other independent variables. RISKFAC has the largest effect on trade attitudes followed by LANDP and LANDRED.

Computer adoption (COMPUT), a proxy for a farmer's progressiveness, has a positive coefficient as hypothesised, implying that respondents who own and use a computer are more likely to favour a liberalised trade environment. Progressive farmers are more likely to adopt relevant technologies which increase their competitive advantage. However, this variable may also capture the effects of other factors such as farm size, farmer's age and level of education as larger, younger and better educated farmers are more likely to use a computer (Woodburn et al, 1994).

A negative relationship for DIST indicates that farmers more distant from a town will oppose free trade. In the past, 21 marketing boards reduced the need for farmers to market their products. In the event of trade liberalisation, farmers will be required to market their products (either themselves or by agents), and locality of potential markets will therefore be important.

Respondents who consider changes in environmental regulations (ENVIRO) as a risk to their businesses are likely to oppose a free-trade environment, as evidenced by a negative coefficient. The South African commercial farming industry has relied on chemicals and commercial fertilizers to produce high yields (Lyne and Ortmann, 1992), whilst environmental restrictions under GATT could include limits or bans on the use of fertilizers, pesticides and herbicides (LaFrance, 1992). Provisions under GATT include revision and tightening of sanitary and phytosanitary measures (Giardini, 1995). In addition to these concerns, issues 
relating to the landscape, conservation, water quality, quality of foodstuffs and animal welfare are to be addressed (MacLaren, 1995). Adherence to certain environmental measures would require additional investment for farmers, thereby increasing their costs of production. Environmental groups are also becoming an effective counter force to traditional farm lobbies (MacLaren, 1995).

A negative coefficient for RISKFAC indicates that respondents who perceive variability in crop prices, changes in the Rand exchange rate, changes in input costs and further reduction in import tariffs as sources of risk, are opposed to liberalisation of trade. This is to be expected as crop prices would be more variable under free trade. Changes in the Rand exchange rate would affect the domestic cost of inputs and prices of imported products, whilst further reduction in import tariffs on agricultural products would also affect local product prices. As hypothesised, respondents who perceive these factors as important sources of risk to their operations would oppose liberalisation of trade. This independent variable has the highest standardised parameter estimate and thus has the Jargest effect on free-trade attitudes relative to other independent variables.

As expected, respondents who think that land prices (LANDP) will rise in the event of the successful implementation of GATT are supportive of a free-trade environment. GATT is synonymous with free trade and this response is therefore rational seeing that increased land prices are of benefit to land owners.

LANDRED, the importance of further land redistribution as a source of risk, is positively related to attitudes towards free trade. Respondents' supportive of free trade probably consider themselves competitive and are likely to survive in a free-trade environment. Respondents' perceptions may indicate that more productive units will not be rediscributed ahead of other less competitive operations.

As expected, variability in livestock prices (LPRICE) has a negative association with the dependent variable. Operators who regard variable livestock prices as an important source of risk are likely to oppose free trade as livestock prices are likely to be more variable under free-trade conditions. 
Table 5: Logit model of attitudes towards free trade by sample farmers in KwaZulu-Natal, $1996(n=70)$.

\begin{tabular}{|l|l|l|l|l|}
\hline Variable & $\begin{array}{l}\text { Parameter } \\
\text { estimate }\end{array}$ & $\begin{array}{l}\text { Standard } \\
\text { error }\end{array}$ & $\begin{array}{l}\text { Asymptotic } \\
\text {-statistic }\end{array}$ & $\begin{array}{l}\text { Standardised } \\
\text { parameter } \\
\text { estimate }\end{array}$ \\
\hline COMPUT & 3,2968 & 1,7066 & $1,93^{*}$ & 1,5868 \\
\hline DIST & $-0,1996$ & 0,0732 & $-2,73^{* * *}$ & $-2,7686$ \\
\hline ENVIRO & $-1,8245$ & 0,6970 & $-2,62^{* *}$ & $-2,8680$ \\
\hline RISKFAC & $-6,4153$ & 2,2851 & $-2,81^{* * *}$ & $-6,4153$ \\
\hline LANDP & 10,1536 & 3,8559 & $2,63^{* *}$ & 3,5825 \\
\hline LANDRED & 2,0176 & 0,7684 & $2,63^{* *}$ & 3,4635 \\
\hline LPRICE & $-1,0460$ & 0,4452 & $-2,35^{* *}$ & $-2,1820$ \\
\hline MFINAN & 2,8454 & 1,0248 & $2,78^{* * *}$ & 2,4708 \\
\hline PORF & 3,8046 & 1,9115 & $1,99^{* *}$ & 1,3373 \\
\hline REPAY & $-2,600$ & 0,9552 & $-2,72^{* * *}$ & $-2,4226$ \\
\hline TLEVEL & $-3,7165$ & 1,7032 & $-2,18^{* *}$ & $-1,5958$ \\
\hline CONSTANT & $-4,2732$ & 2,8689 & $-1,49$ & 7,2305 \\
\hline Model Chi- & $46,163^{* * *}$ on 11 degrees of freedom \\
\hline square & & & & \\
\hline Goodness of fit & 27,393 (N.S.) on 58 degrees of freedom \\
\hline Correct prediction $(p e r c e n t)$ & & & \\
\hline Total & 88,57 & & & \\
\hline Agree & 92,59 & 75,00 & & \\
\hline Disagree & & & \\
\hline
\end{tabular}

Note: ", "," ${ }^{\prime *}$ indicate significance at the 10 percent, 5 percent and 1 percent levels of probability respectively. 
Respondents with a higher self-rating of management skill in farm finance (MFINAN) are supportive of a free-trade environment. Above-average financial managers are better equipped to manage increased price risk associated with market forces by controlling financial risk. Following economic liberalisation, farmers in New Zealand reduced fixed financial repayment obligations by reducing debt levels (Robinson, 1995).

The positive PORF coefficient suggests that full-time farmers are in favour of a liberalised trade environment. This is contrary to expectations and the results reported by Edelman and Lasley (1988) and Barkley and Flinchbaugh (1990). In this study, respondents farming on a full-time basis may have a greater incentive to adapt to a market-orientated economy in order to satisfy household consumption needs. These farmers may have more time available to investigate different marketing altematives and to identify and respond to market signals.

A negative relationship exists between attitudes towards free trade and debt repayment levels (REPAY). Following economic liberalisation in New Zealand in 1984, the real price of farmland decreased from 1095 dollars per hectare in 1984 to 569 dollars per hectare in 1989 (Johnston and Frengley, 1991). Consequently, farm households whose debt exceeded 50 percent of total assets increased from 10 percent of households in 1985 to nearly 24 percent in 1986. This proportion of farmers with high debt levels subsequently declined due to debt restructuring and farm sales (Johnston and Frengley, 1994). Lower levels of debt are now evident as farmers seek to have a financial buffer to protect themselves from a future economic downtum (Robinson, 1995). Given the potential decline in land values, operators with higher debt levels are possibly aware of the probable effect of free trade on their debt/asset ratio. The anticipated increase in price risk associated with trade liberalisation, in addition to the level of financial risk associated with borrowed capital, may be a matter of concem.

Respondents who indicated that they knew the level of import tariffs on products they produced or inputs they used (TLEVEL) were opposed to free trade. Seventy-seven and 90 percent of respondents, respectively, did not know the tariff level on products they produced or inputs they used. More respondents have an expectation regarding the effect of tariff removal on reduced product prices (negative effect on farm business) than on reduced input prices (benefit to farm business), which might explain the negative relationship. This result may imply that farmers have not sought information, or need more information, on the level of tariffs on imported goods, particularly on the potential benefits (decreased costs) to the farm business of reduced (abolished) tariffs on imported inputs. 


\section{Logit model of attitudes towards deregulated domestic markets}

Logit analysis was also used to establish the personal and business characteristics (considered in a previous analysis) influencing farmers' attitudes towards deregulated domestic markets. The logit model adapted from equation (1) is used to predict that a respondent will strongly agree with the statement given.

Only three percent of respondents disagreed with the statement regarding deregulated domestic product and input markets (last question in Table 3). Consequently, respondents who 'agreed' with the statement given were coded as zero, whilst those who 'strongly agreed' were coded as one. After investigating variables considered in the previous analysis, only variables with coefficients significant at the ten percent (or higher) level were retained in the model. These include DAIRY, EXP, MFINAN and RISK all of which are defined in Table 4. Results of the analysis are presented in Table 6.

The model's Chi-square statistic is highly significant. The goodness of fit statistic shows no significant lack of fit in the overall model. The estimated model correctly classifies 96,10 percent ( 74 of 77 ) of those who 'agree' and 42,86 percent ( 9 of 21$)$ of those who 'strongly agree' with market deregulation, yielding an overall correct classification rate of 84,69 percent ( 83 of 98 ). Zero-order correlation coefficients were all less than 0,19 and there were no relationships significant at the five percent level, thus multicollinearity is not suspected. Of the independent variables included, MFINAN has the highest standardised coefficient indicating the relatively large effect it has on attitudes towards market deregulation.

Respondents who derive more than 55 percent of their gross income from dairy production are more likely to strongly agree with deregulation of domestic product and input markets. These (dairy) respondents possibly perceive significant benefits from the deregulation of the maize (feed) industry and improved marketing opportunities, as product differentiation and adding value to milk (eg cheese and yoghurt) may be feasible alternatives

Years of farming experience (EXP) is negatively related to deregulation attitude, indicating that less experienced farmers are more likely to agree with market deregulation than more experienced producers. The latter could be less suspicious of government programmes' complex regulations (Kastens and Goodwin, 1994).

Respondents who have a higher self-rating of management ability in farm finance (MFINAN, which also has the highest standardised parameter estimate), are more likely to strongly agree with market deregulation. Skilled financial 
managers may be able to exercise prudent purchasing of inputs and should also be better able to manage increased price risk associated with deregulated markets.

Willingness to take risks (RISK) was positively related to deregulation attitudes. Increased price risk associated with the deregulation of product markets is less likely to be perceived as a problem by farmers who are more willing to take risks.

Table 6: Logit model of attitudes towards deregulated domestic markets by sample farmers in KwaZulu-Natal, $1996(n=98)$.

\begin{tabular}{|l|l|l|l|l|}
\hline Variable & $\begin{array}{l}\text { Para- } \\
\text { meter } \\
\text { estimate }\end{array}$ & $\begin{array}{l}\text { Standard } \\
\text { error }\end{array}$ & $\begin{array}{l}\text { Asymptotic } \\
\text {-statistic }\end{array}$ & $\begin{array}{l}\text { Standardised } \\
\text { parameter } \\
\text { estimate }\end{array}$ \\
\hline DAIRY & 1,74943 & 1,1011 & $1,59^{*}$ & 0,3957 \\
\hline EXP & $-0,0641$ & 0,0261 & $-2,46^{* *}$ & $-0,8653$ \\
\hline MFINAN & 1,3482 & 0,4602 & $2,93^{* *}$ & 1,1707 \\
\hline RISK & 0,7865 & 0,3427 & $2,30^{* *}$ & 0,7756 \\
\hline CONSTANT & $-7,5856$ & 2,3161 & $-3,28^{* *}$ & $-1,9576$ \\
\hline Model Chi-square & $24,600^{* * *}$ on 4 degrees of freedom \\
\hline Goodness of fit & 90,266 (N.S.) on 93 degrees of freedom \\
\hline Correct prediction (percent) \\
\hline Total 84,69 \\
\hline Agree \\
\hline Strongly agree & 42,86 \\
\hline
\end{tabular}

Note: $,^{* *},{ }^{* * *}$ indicate significance at the 10 percent. 5 percent and 1 percent leveis of probability respectively.

\section{CONCLUSIONS}

Most respondents support a liberalised trade environment but foresee a reduction in product prices, farm profits and land values if GATT provisions are successfully implemented. A possible reason for this apparent anomaly is the additional source 
of risk associated with potential changes in government agricultural policy. Following agricultural liberalisation in New Zealand, farmers were faced with changes in prices and the economic environment but considered these more modest and predictable than government's reactions to political demands (Robinson, 1995). Respondents are also aware of the imponance of becoming more competitive on domestic and international markets.

A large proportion of respondents, however, did not know the level of import tariffs on the products they produced ( 77 percent) or inputs they used $(90$ percent). The perceived knowledge of tariff levels (TLEVEL) negatively affects attindes towards free trade because more farmers knew about the negative effect of reduced import tariffs on their product prices than about the cost-saving effect (positive) of lower tariffs on imported inputs. More information on import tariffs and their effects could improve farmers' perceptions of free trade, particularly information on how lower tariffs affect prices of imported inputs. Information channels could include publications frequently used by farmers, more industryspecific information provided by industrial publications or the electronic media.

Sixty percent of respondents intended seeking additional information about GATT. Information regarding expected price changes and the implications of the GATT provisions may also be useful to farmers in planning the future direction of their businesses.

Seeking more marketing information to aid management decisions and adding value to their products, were cited as responses to reduced agricultural support. Production responses included increasing the size of current enterprises to take advantage of economies of size, adding a new enterprise (diversification) and changing the size and mix of current enterprises. Opportunities exist for private consultants, who are considered by 22 percent of respondents as a potential source of information (but currently used by only 10 percent of farmers), to advise farmers in these areas, particularly in product marketing as farmers consider their skills in this area to be relatively poor.

The low envisaged use of futures markets (by 10 percent of respondents) could be improved by increasing the range of futures contracts (eg more crop contracts) and/or educating farmers on the functions and principles of futures markets. This could help farmers in managing price risk as more variable prices are expected with trade liberalisation.

Respondents who perceive sources of risk captured by ENVIRO, RISKFAC and LPRICE to be important are opposed to free trade. Farmers who are relatively risk averse (RISK) are also less likely to favour market deregulation. High standardised parameter estimates for RISKFAC and LANDRED indicate the 
relative importance of these risk sources on perceptions of free trade. Increased price risk is expected with free trade and market deregulation. To improve farmers' ability to survive in the changing policy environment and to avoid resistance towards trade liberalisation from risk-averse producers, improved information flows and education regarding methods of altering financial, marketing or production techniques to manage risk could be pursued (Barry et al, 1995). Self-rating of managerial ability in farm finance may improve, thereby reducing debt repayment levels which would also improve perceptions of free trade.

Small-scale emerging farmers are likely to have less information and knowledge of risk management strategies than large-scale commercial farmers. Consequently, government extension services may have an important role to play in disseminating information and educating small-scale producers on risk management strategies in a changing trade environment.

\section{REFERENCES}

1. BARKLEY, A.P. and FLINCHBAUGH, B.L. (1990). Fam Operator Opinion and Agricultural Policy; Kansas Survey Results. North Central Journal of Agricultural Economics, 12(2), 223-239.

2. BARRY, P.J., ELLINGER, P.N., BAKER, C.B. AND HOPKIN, J.A. (1995). Financial Management in Agriculture. Fifth Edition, Interstate Publishers, Inc. Danville, Illinois, USA.

3. DEPARTMENT OF AGRICULTURE (1994). The General Agreement on Tariffs and Trade: Background and Implications for South Africa. Directorate: Marketing, Pretoria, February 1994.

4. EDELMAN, M.A. and LASLEY, P. (1988). An Analysis of the Agricultural and Trade Policy Preferences of lowa Operators. North Central Journal of Agricultural Economics, 10(2), 243-254.

5. GIARDINI, G. (1995). Farm Policy Reform in the European Community: Main Features and Trade Effects. Unpublished paper, Institute of Agricultural Economics and Policy, University of Bologna, Italy.

6. GOLDIN, I. and KNUDSEN, O. (1990). Agricultural Trade Liberalization: Implications for Developing Countries. Organisation for Economic Development. The World Bank, Washington DC. 475-485. 
7. GUJARATI, D.N. (1995). Basic Econometrics (Third Ed.). McGraw-Hill Publishing Co., Singapore.

8. JOHNSTON, W.E. and FRENGLEY, G.A.G. (1991). The Deregulation of New Zealand Agriculture: Market Intervention (1964-84) and the Free Market Readjustment (1984-90). Western Journal of Agricultural Economics, 16(1), 132-143.

9. JOHNSTON, W.E. and FRENGLEY, G.A.G. (1994). Economic Adjustments and Changes in Financial Viability of the Fanning Sector: The New Zealand Experience. American Journal of Agricultural Economics, 76(5), 1034-1040.

10. JOSLING, T. (1993). Multilareralism: A Constraint on Unilateralism and Regionalism in Agricultural Trade. American Journal of Agricultural Economics, 75, 803-809.

11. KASTENS, T.L. and GOODWIN, B.K. (1994). An Analysis of Fanners Policy Attitudes and Preferences for Free Trade. Joumal of Agricultural and Applied Economics, 26(2), 497-505.

12. LAFRANCE, J.T., (1992). Environmental Policy and GATT Negotiations: Discussion. American Journal of Agricultural Economics, 74(3), 782-784.

13. LYNE, M.C. AND ORTMANN, G.F. (1992). Suggestions for Agricultural Economics Research in South Africa. Agrekon, 31(4), 205-209.

14. LYNE, M.C. AND ORTMANN, G.F. (1996), Estimating the Potential for Creating Additional Livelihoods on Commercial Fannland in KwaZuluNatal. In M. Lipton, F. Ellis and M. Lipton (Eds.), Land, Labour and Livelihoods in Rural South Africa, Vol. 2: KwaZulu-Natal and Northern Province, Ch. 3. Indicator Press, Durban.

15. MACLAREN, D. (1995). The Uruguay Rotand Agreement on Agriculture: A New World Order for Agricultural Trade? Review of Marketing and Agricultural Economics, 63(1), 51-63.

16. NIEUWOUDT, W.L. AND VINK, N. (1995). Financing of land purchase by small-scale farmers. Development Southern Africa, 12(4), 507-517.

17. ORAZEM, P.F., OTTO, D.M. AND EDELMAN, M.A. (1989). An Analysis of Farmers' Agricultural Policy Preferences. American Joumal of Agricultural Economics, 71(2), 837-846.

18. PHILLIPS, J. (1973). The Agriculural and Related Development of the Tugela Basin and its Influent Surrounds. A report by Town and Regional Planning, Pietermaritzburg. 
19. ROBINSON, S.A. (1995). Trade Policies and their Effects on Farming: A New Zealand Farmer's Experience. Proceedings: Tenth International Farm Management Congress, University of Reading, United Kingdom, 23-35.

s20. SCHUH, G.E. (1995). Trade Policies and their Effects on Farming. Proceedings: Tenth International Farm Management Congress, University of Reading, United Kingdom, 9-35.

21. SWART, P.J.A. (1996). South African Agriculture in the World Economy. Agrekon, 35(4), 200-203.

22. WOODBURN, M.R., ORTMANN, G.F. AND LEVIN, J.B. (1994). Computer Use and Factors Imfluencing Computer Adoption Among Commercial Farmers in Natal Province, South Africa. Computers and Electronics in Agriculture, 11, 183-194. 